\title{
Os Terrenos de Marinha e a Reforma Administrativa
}

PAULO B. DE ARAÚJO LIMA

Procurador do Estado da Guanabara

INTRODUÇÃO

$\S 10$ - Da Reforma Administrativa e seus objetivos.

$\S 2$ - A extinção dos terrenos de marinha como medida de interesse à Reforma.

A Reforma Administrativa, cujas bases foram lançadas pelo Decreto-lei n० 200, de 25 de fevereiro de 1967, se propõe a simplificar e aperfeiçoar o funcionamento da máquina administrativa federal de modo a proporcionar-lhe maior economia e mais rendimento.

Dentre as várias medidas programadas a esse fim, têm especial relevo não só aquelas concernentes à racionalização da minecânica do processo administrativo, onde só terão atuação os componentes administrativos indispensáveis à formação da vontade do Estado (agentes de planejamento, coordenação Q execução), como também a própria extinção de certos serviços e repartições que, mantidos até hoje por mera tradição consuetudinária, já se mostram inúteis e desnecessárias à consecução da coisa pública.

Afinando-se com esse espírito, o presente trabalho vai tentar demonstrar a inutilidade de se manter no domínio da União Federal os chamados terrenos de marinha, quer porque a instituição não apresenta vantagem de natureza política, administrativa ou estratégica, quer porque, longe de consistir em ponderável vantagem econômica, representa um fator a mais de custos a gravar o funcionamento do aparelho burocrático federal. 
Para fazê-lo, e com intuito de emprestar à exposição uma seqüência lógica, vamos começar pela análise do instrumento jurídico que serve de suporte ao instituto dos terrenos de marinha - a enfiteuse, aforamento ou emprazamento.

Vamos inicialmente referir-lhe as origens, dar-lhe os contornos doutrinários, mostrar como e em que circustâncias passou ao Direito brasileiro, para depois tratar dos terrenos de marinha a seu prisma.

\section{Parte Primeira \\ DA ENFITEUSE}

CAPITULO

tuais. Finalitense. Suas origens e elementos concei-

Aocial do instituto.

Existe uma certa controvérsia em localizar-se no tempo as
origens da enfiteuse.

A propósito, alguns autores remontam à civilização helêni$\mathrm{ca}$, aduzindo que o Império Romano ao expandir suas fronteiras, foi encontrar e assimilar o instituto nas províncias gregas, incorporando-o ao seu sistema jurídico. Dentre esses aponta-se De Ruggiero e, entre nós, Dionízio Gama, Agapito Veiga e Al-
fredo de Almeida Paiva.

Já outros, entre os quais se encontra Lafaiette (Direito das Coisas) situam seu nascimento no próprio Direito romano, vislumbrando no ager pubblicus (instituto pelo qual se cobrava dízimos de quem explorava campos públicos) a sua célula-

Seja como for, a enfiteuse (palavra grega que significa plantar em) foi, pouco a pouco sendo reformulada pelo Direito romano, e, com as características que então Ihe foram atribuíleiro, apareceu nos Códigos Civis modernos, inclusive o brasi-

$O$ instituto consiste basicamente na entrega de um bem imóvel - e haverá de ser sempre um bem imóvel - a outrem, para que este o explore mediante certa retribuição - o pagamento de um foro ou pensão anual.

$\mathrm{Na}$ sua aparência, assemelha-se à locação ou arrendamento, pois que aqui também se trata de entregar a outrem uma coisa para que este a usufrua mediante certa retribuição pe-
cuniária.

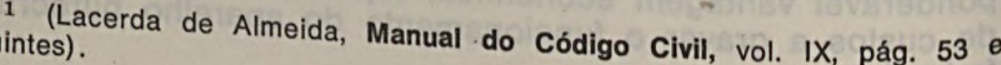


A similitude, porém, não passa de simples aparência. $\mathrm{Na}$ verdade - de parte as colocações de doutrina jurídica, que não vêm a pelo senão referir (nesta se trata de direito real, nas locações de direito das obrigações) - , a enfiteuse distingue-se nos seguintes pontos essenciais.

Em primeiro lugar, a disponibilidade econômica que se transfere ao enfiteuta transcende de muito os elementos restritos da locação. A disponibilidade que este tem da coisa dada em aforamento é a mais completa possível.

Partindo-se do conceito de propriedade, que consiste em essência na integral disposição econômica do bem (ou, na sua acepção liberal, hoje filosoficamente superada, utere et abutere), verifica-se que na enfiteuse se transmite quase a propriedade ou o domínio da coisa. Basta referir que o enfiteuta pode alienar sob todas as formas conhecidas o imóvel (venda, permuta, doação etc.), bem como gravá-lo através de hipotecas, penhores industriais ou rurais, além de perceber-lhe todos os frutos civis e industriais. ${ }^{2}$

Assim, ao passo que o locatário tem o uso restrito da coisa locada, pois que só pode usá-la nos fins previstos no contrato e deve cuidá-la com a prudência do bom varão, respondendo pelos danos que Ihes der causa, o enfiteuta age com relação ao bem com a mais completa autonomia de vontade e interesse como se proprietário fosse.

E tão contundente é o fenômeno que os próprios juristas discutem acesamente, no plano doutrinário, se não é o enfiteuta (titular do domínio útil) o verdadeiro proprietário do imóvel, ao passo que não seria e enfiteuticador, com direito a uma mera pensão anual e, evidentemente, a laudêmios, aquele que, em realidade, tem direito sobre a coisa. ${ }^{3}$

De outra parte, a enfiteuse se caracteriza pela manifesta desproporção entre a retribuição paga pelo enfiteuta e a fruição que se tem do imóvel aforado, ainda, nesse passo, aprofundando suas divergências com a locação e fortalecendo, por outro lado, a tese daqueles que sustentam ser o enfiteuta 0 verdadeiro proprietário.

2 (Código Civil - Clóvis Bevilacqua, vol. III.)

3 A única restrição de natureza econômica que tem o enfiteuta com relação ao bem dado em enfiteuse é a de não poder desmembrá-lo em giebas sem o consentimento do senhorio direto.

fo dispositivo que, de resto, destoa dos demais poderes conferidos ao foreiro vem evidentemente de encontro aos possiveis interesses do senhorio de manter a unidade territorial de seus campos. 
De fato - conquanto na locação, conforme já se referiu, o uso da coisa seja restrito e subordinado aos fins impostos pelo proprietário no contrato respectivo e na enfiteuse a disponibilidade econômica seja praticamente integral —, na primeira a retribuição pecuniária é muito mais expressiva do que
na segunda.

Na verdade, o foro devido, além de ser anual, fixo e imutável, representa uma prestação ínfima (em geral $0,6 \%$ ao ano do valor da propriedade) enquanto que na locação a retribuição, de regra, é mensal e representa um valor de maior expressão

Ainda, ao contrário da locação, o aforamento é perpétuo. Vale dizer, uma vez constituído não se extingue mais a não ser por culpa do enfiteuta (mora nas obrigações assumidas no
contrato).

Dessa forma, uma vez constituído o aforamento, o enfiteuticador (salvo casos excepcionais de comissão) não pode mais contar senão com os foros anuais, e, eventualmente, laudêmios, ao passo que 0 enfiteuta incorpora definitivamente 0 imóvel ao seu patrimônio.

E essa característica é sumamente importante, como se verá mais adiante, pois, sendo perpétuo o aforamento, a pensão fixada será sempre imutável, eis que ajustá-la seria fazer novo contrato enfitêutico, não sendo por outra razão que a própria

Por fim, a enfiteuse só pode incidir sobre terras não cultivadas e terrenos destinados à edificação.

Quer dizer, não há como constituir o aforamento em terras em processo de produção ou prédios. Haverá forçosamente de se tratar de glebas incultas e terrenos abandonados onde for necessário fundar vilas, lugarejos etc.

Além desses, outros elementos, posto que pouco expressivos para a projeção de suas finalidades sociais, são peculia-
res ao instituto.

Dessa forma, o enfiteuticador ou senhorio direto tem preferência à aquisição do domínio útil do bem aforado. E, caso não a exerça, tem direito a receber um laudêmio quando da alienação, o qual, segundo o Código Civil, corresponde a 2,5\% do valor do domínio do imóvel e a $5 \%$ em se tratando de enfiteuse pública, conforme as leis administrativas específicas. 
Caso o enfiteuta não pague por três anos consecutivos a pensão (que é anual) o aforamento cai em comisso, reintegrando-se o domínio do imóvel no patrimônio do senhorio direto, mediante indenização das benfeitorias.

Ainda, o enfiteuta não pode rescindir por vontade ou interesse próprio a enfiteuse, que, como se disse, é perpétua (o que, a rigor, significa uma obrigação de cultivar e edificar para, habilitando-se economicamente, pagar o foro devido. Assiste-lhe, porém, o direito de abandonar o imóvel ao senhorio direto, caso este, deteriorando-se, passe a valer menos que o capital equivalente a um foro e $1 / 5$ deste (Código Civil, arts. 687 e 692).

Um exame, mesmo que superficial, de seus contornos conceituais, revela logo que a enfiteuse se presta essencialmente à colonização de terras, sendo o instrumento legal, pelo qual então se promovia o cultivo de glebas improdutivas e se estimula$\mathrm{va}$ a edificação de prédios. Através dele, captava-se o pioneirismo daqueles que se dispunham a tomar posse de terras longínquas e estéreis, fazendo-as produzir.

Daí por que, em compensação aos incômodos do pioneirismo, dever-se-ia acenar ao foreiro com mais que uma simples posse de natureza restrita, como o é a da locação. A perspectiva que se lhe abria era de estoicismo e esforço, e haver-se-ia de cativá-lo com mais alguma coisa, garantindo-lhe juridicamente uma completa fruição econômica do imóvel.

Não Daí por que a retribuição deveria ser módica e razoável. aproximando o instituto da locação, até porque, a rigor, nada havia que arrendar. O valor patrimonial da terra, deveria o enfiteuta criá-lo, através de seu esforço e trabalho.

Dai por que, outrossim, o instituto deveria ser perpétuo ou por prazo de uma vida (como também o havia no Direito antigo). O trabalho do foreiro no cultivo da terra é que lhe atribuía o valor. Seus primeiros passos eram como de um ocupante de duzir. Sua posse, nessas condições, não deveria sofrer injunção de prazo.

Um exame do instituto, a outro ângulo, vai igualmente revelar que, a par de sua finalidade eminentemente colonizadora, o aforamento se presta também a um instrumento de aferição de renda. 
Conquanto a pensão paga pelo foreiro seja, em si, módica e fato, como um instrumento de captação de rendas pelos respec-

O Código Civil Brasileiro, buscando dar ênfase às finalidades do instituto e contê-lo na sua estrutura original estatuiu que só se constituirá o aforamento sobre terras incultas e terrenos destinados a edificação (art. 680).

Bem examinadas as coisas, porém, verifica-se que o dispositivo, posto que coerente com a doutrina, se revela, no fundo,
inteiramente inócuo.

$\mathrm{Na}$ verdade, nenhum interesse econômico teriam os donos de terras em aforar terras cultivadas ou prédios existentes. Percebe-se que a ninguém ocorreria outorgar a outrem a completa fruição econômica de imóvel em produção e, portanto, de valor palpável, em caráter perpétuo e mediante ínfima remuneração. O negócio, em $\mathrm{si}$, como vantagem patrimonial, repugnaria mes-
mo àqueles providos apenas de bom senso.

Sente-se, até por intuição, que o instituto está intimamente ligado a uma organização política e econômica, hoje inteiramente ultrapassada, em que léguas de terras eram outorgadas a nobres, guerreiros, clero, influentes nas cortes etc., em extensões seriam incapazes de integrá-los economicamente ao seu patrimônio. A propriedade de terras tinha, então, mais um caráter político, mais um sentido de poder do que propriamente um sig-
nificado patrimonial de expressão.

Daí a excogitação de um instituto, como a enfiteuse, pelo qual o senhorio, sem condições de usufruí-lo ele próprio, pudesse transferir o domínio útil das terras a outrem, provendo a colonização e, ao mesmo tempo, auferindo as rendas corres-
pondentes.

Se atentarmos um pouco para as peculiaridades do aforamento, verificaremos que tanto o foro, com seu caráter certo $e$ invariável, sua perpetuidade e modicidade, como o laudêmico, pelas suas características, mais se aproximam de um tributo priedade fundiária tinha uma enfática conotação política, promais transcendente, nítida e exprtica conotação política, muito nômico. E, se quisermo expressiva do que o seu valor ecocluir que a enfiteuse ñ nos deter mais um pouco, vamos conum pouco mais sofistico passaria da mesma fórmula - apenas 
pelo que se cobravam dízimos sobre a exploração de campos públicos. ${ }^{4}$

$\mathrm{Na}$ verdade, se ponderarmos mais o fato, vamos sentir que o aforamento se prestava muito mais a uma organização política do que era representativo de um negócio patrimonial que se pudesse fazer com a propriedade. A extensão das vantagens concedidas sobre o imóvel, a perpetuidade, as características da remuneração ao senhorio, tudo conspira nesse sentido.

Aliás, CARVALHO SANTOS 5 refere que $o$ instituto da enfiteuse ou aforamento, embora de origens romanas, prestou-se admiravelmente à organização política que predominou na Idade Média.

Os praxistas medievais, segundo diz, manipulando o instituto, criando sobre ele a teoria de dualidade de domínios ou superposição de propriedades, articularam todo o arcabouço da organização político-administrativa de então, que, como se sabe, caracteriza-se pela pulverização do poder político e da autoridade administrativa.

Armando em torno da enfiteuse a teoria da dualidade ou superposição de domínios, servindo-se largamente da subenfiteuse, estendendo o instituto a prédios e construções já existentes, os praxistas medievais conseguiram estabelecer, no plano jurídico, a coexistência de coroas, principados, ducados etc., cada qual constituindo um núcleo dotado do poder político e auferindo rendas próprias.

Segundo completa LAURENT (apud, Alfredo de Almeida Paiva, Rev. de Dir. Administrativo, vol. XIII, págs. 514 e seguintes), no que é corroborado por LOBÃO ("Direito Enfitêutico", págs. 15 e seguintes), a Idade Média ampliou, à sua feição, os contornos da enfiteuse, estabelecendo, a par da obrigação de pagar foro, uma série de encargos correlatos (lutuosas), através dos quais príncipes, duques, etc. prestavam-se, reciprocamente, serventia ou vassalagem (principalmente o serviço militar; e todos a prestavam ao suserano, a quem cabia o domínio superposto ou o domínio eminente sobre as terras, sustentando, no plano teórico, os costumes políticos então vigentes.

4 A própria perpetuidade do aforamento, obrigando o foreiro e seus sucessores a pagar pela vida inteira ao senhorio direto o foro respectivo, dá a verdadeira dimensão eventual do instituto, que participa muito mais da natureza de um tributo sobre a terra do que de uma avença do mundo civil.

5 Ob. cit., vol. IX, pág. 40. 
$\S 10$ - A enfiteuse, um instituto em decadência.

§ 2 : -0 episódio do Código Civil.

$\S 3$ ? - A orientação da Suprema Corte.

Os tempos foram se passando, e as instituições foram $\mathrm{mu}$ dando. A economia deixou de ser essencialmente fundiária para venções se sucederamal, de valores mobiliários; as grandes innicas, novas possibilidadescionando à humanidade novas téca um impressionantidades de riquezas; o século XIX assistiu não havia mais lute acúmulo de capitais, e, em breve tempo, decadência.

Não havia mais as grandes extensões de terras incultas a aforar. O progresso, as maiores facilidades de comunicação e locomoção tiraram das terras incultas aquele seu significado anterior. Mesmo quando incultas, as facilidades e rapidez de

$E$ nem as regras políticas já então vigentes autorizavam, pudessem aforar. ${ }^{6}$ Por outro lado, as crises econômicas abalaram a estabili-
dade das posições patrimoniais e vieram mostrar tibilidade com instrumentos jurídicos mostrar sua incompaduzindo virtualmente a valor zero je natureza perpétua, rese fizeram em torno do afor zero as avenças pecuniárias que Eo certo e que, quando, afinal, digo Civil Brasileiro quando, afinal, em 1916, o Projeto do Cónal, o problema da veio a ser discutido no Congresso Nacio6 Segundo refere

Civil, vol. III, págs. 270 e Washington de Barros Monteiro (Curso de Direito nobreza e clero renunciaram intes), na célebre noite da Queda da Bastilha, privilégios incompativeis com a seus contratos enfitêuticos então tídos como Ainda, a propósito, completan o sopro das novas idélas.

ralmer no sentido de que o Código refivil francia, vale o comentário do mesmo tarde, em 1902 promulgado, aboliu do seu texto a enfiterito da revolução

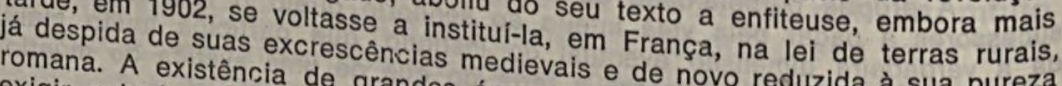
exigir colonizaçấo, teria prandes áreas rurais a essa réuzida à sua pureza a lei de terras rurais. 
Para alguns, o instituto, em franco declínio, deveria ser excluído da lei civil brasileira, pois, representando um resquício de organizações políticas superadas, não merecia figurar em um código moderno como o brasileiro. ${ }^{7}$

Para outros, posto que em processo de extinção, o instituto poderia ainda servir à Nação, dada a sua grande extensão territorial, com áreas então ainda praticamente desabitadas.

Além do mais, quando o Código Civil houvesse de se tornar lei, haveria de encontrar, de qualquer forma, enfiteuses já constituídas. E, sendo um código, um compêndio orgânico de propriedade privada, não poderia ignorá-las.

Afinal prevaleceu o ponto de vista - de resto adotado na maioria dos países que também inseriram em seus códigos a enfiteuse: colocar entre seus dispositivos um de ordem pública e irrenunciável, pelo que o foreiro, após certo lapso de tempo, pudesse resgatar o domínio útil mediante o pagamento de cer-

7 Aliás não seria só a enfiteuse que já em 1916, estaria em processo de decadência. Certos direitos reais, por seu feitio peculiar e suas finalidades, já àquela época, vinham perdendo atualidade. O direito real de uso, o de habitação, as rendas constituídas sobre imóveis e mesmo o usufruto por ato inter vivos, àquele tempo - e hoje com maioria de razão se pode dizer que são peças de museu - vinham perdendo o sentido. De fato, esses direitos reais consistem basicamente em despir-se a propriedade imóvel, de regra, em caráter permanente, de um ou alguns de seus componentes patrimoniais, para atribuí-lo a outrem que passa a ter um direito à substância da coisa. Quem outorga o direito como que desmembra a área patrimonial da propriedade para atribuí-la, em parte, a terceiro. O benefício de direito de propriedade, a gama de fruições de ordem econômica que ele contém como que reparte-se entre o proprietário; que deixa de ter o domínio pleno sobre o bem, para ter sua propriedade gravada a terceiro, que assim adquire o direito real de fruir autonomamente o bem naquele aspecto, como se, àquele ângulo restrito da propriedade, proprietário fosse. Assim, no direito real de uso e habitação (arts. 742 a 748 do Código Civil), o titular do direito tem a função econômica do bem, ao aspecto restrito do uso e da habitação. E essa faculdade de usar e habitar a coisa, ele a exerce com a autonomia de vontade e interesse do proprietário, podendo opor esse exercício até ao próprio titular do dominio que se acha desmembrado. $\mathrm{Na}$ renda constituída sobre imóveis, o proprietário aliena o imóvel com a cláusula de o adquirente pagar uma renda determinada a terceiro indicado pelo alienante. Quem o adquirir posteriormente fica jungido à obrigação que grava o imóvel. No usufruto, o usufrutuário enfeixa todos os aspectos econômicos da propriedade, seus frutos civis e industriais, restando ao proprietário tăo-somente a nua propriedade. Vê-se, claramente, porém, que esses direitos, como, de resto, a enfiteuse, projetam-se sobre uma organização social e econômica já superada. Uma sociedade em que o proprietário concentrava na sua pessoa um grande número de propriedades imóveis, de modo que podia perfeitamente desmembrar algumas no seu aspecto econômico, sem afetar-the o patrimônio e poder. Por outro lado, o único capital Social; a riqueza da comunidade, era quase que exclusivamente a terra, e suas benfeitorias e a utilidade marginal desse capital era de pouca expressão, 
ta importância (na lei brasileira, antes 30 , agora 20 foros), incorporando ao seu patrimônio a propriedade plena do imóvel. ${ }^{8}$

Com o dispositivo, tal qual em outras legislações, dispunha-se de modo a promover a sua extinção gradativa.

Decerto, como assevera Clóvis Bevilácqua (Direito das Coisas, vol. 2, pág. 280), alguns países, embora agasalhassem na sua legislação antiga o aforamento, aboliram-no de seus Códigos. Assim o fez a Suiça e a maioria dos Códigos sulamericanos, como o uruguaio, o argentino, o boliviano e o peruano. O Código Civil francês desconheceu-o, embora, mais tarde, se viesse restaurá-lo em lei especial (lei de terras rurais). O Código alemão retirou-o do seu corpo, colocando-o na lei de introdução, à guisa, evidentemente, de um direito transitório.

$E$ outros, conquanto regulassem a enfiteuse, previram o seu resgate. Além do nosso, o português, o belga e o italiano. O primeiro, aliás, preocupado com a força de sua tradição nacional, que, se serviu à larga do instituto com suas caracterís-

de modo a ensejar esses atos de disposição sobre os bens. A terra foi adquirida não em função da capacidade econômica, mas do poder político, e, ções, os contratos se prestava. Ao passo que a constituição das obrigatitular do ato objetiva tuição de um direito uma vantagem econômica quando o pratica, a consticorrespondia exatam real, representando um fracionamento da propriedade, ter o beneficiário - Com ele, seu titular objetivava mansua área da influêncio usufrutuário, o titular do uso ou da habitação - sob ses econômicos. Co que fazer com ele um negócio visando interesfavorecer filhos, entead esses institutos, dava-se curso aos costumes de tardos, dando-lhes condos, afilhados, protegidos de toda a sorte e até basos sob sua órbita de influões de subsistência e, ao mesmo tempo, mantendoforam passando para váriasia. Mas os costumes mudaram, as propriedades constituir também de valor mãos, o capital das comunidades passou a se imóvel como parcela desteres mobiliários, expandiram-se os mercados, e o de sorte que a outorga de capital passou a ter uma expressão muito maior, da propriedade, passou a ser direitos, com o conseqüente esfacelamento míssel, e os institutos entraram renúncia econômica muito grande, inadnotários nunca tenham ouvido em decadência. Hoje é bem possível que os constituídas sobre imóvel etc.

8 Aliás, mesmo depols

Código Civil, a adoção da de superado o episódio com a promulgação do No decorrer dos anos, o instituto so no nosso Direito nunca foi tranqüila. a ditadura Vargas (1944), elaborou-seu increpações de toda ordem. Durante leiro. Mais tarde, Hermes Lima, entã projeto, abolindo-a do Direito brasin? 283/46) propondo sua retirada do deputado (1946), apresentou projeto palavras de João Mangabeira: "pe do Direito pátrio. São dessa época as "peça do mundo antigo e base do regime 
encargos correlatos na enfiteuse - as famosas lutuosas. O italiano, sem capitular o laudêmio, tendo-o, possivelmente, como uma excrescência medieval, já que o Direito romano dele não cogitava. Ilóvis, ob. cit.). ${ }^{9}$

Mas, conquanto o objetivo do resgate fosse, em essência, a extinção gradativa da enfiteuse, o dispositivo revelou-se inócuo durante muito tempo.

De fato, louvando-se possivelmente no magistério do insigne Clóvis, que, por sua vez, se apoiava na obra magistral de GARBA sobre irretroatividade das leis, a Suprema Corte - não sem dissenções as mais expressivas - sustentou, durante muitos anos, não aplicar-se às enfiteuses constituída anteriormente ao Código Civil o dispositivo do resgate.

Acontecia, então, que ninguém, em pleno século $X X$, a não ser por insólita extravagância, iria dar em aforamento suas propriedades. Ninguém, com efeito, iria despojar-se, em caráter perpétuo, dos componentes patrimoniais de sua propriedade em troca de ínfima pensão anual. As formas de aquisição e disponibilidade dos bens imóveis, a própria projeção que os bens de raiz têm sobre o patrimônio dos indivíduos, já levavam outro sentido e brigavam com o feitio do instituto.

feudal, nada justifica esse cativeiro perpétuo do trabalho, ao dono da terra que não a desbrava, não a cultiva; não a explora. Essa vassalagem, característica da servidão feudal, só por um preconceito injustificável pode ser atualmente conservada." E de Orosimbo Nonato: "A enfiteuse é um direito residuai, é um survival da Idade Média, é um direito com feição feudalista. A tendência moderna é no sentido de sua extinção."

9 Alguns comentaristas do Código Civil - entre eles Carvalho Santos - pretendem ver no dispositivo do resgate mais a adoção de um princípio de equidade em favor do foreiro. Pretendem ver no resgate o oferecimento de oportunidade ao foreiro para consolidar no seu domínio a propriedade plena do imóvel.

Parece-nos, contudo, que não se pode fazer equidade a alguns à custa de iniqüidade a outros. Se o foreiro tem interesse em consolidar na sua pessoa a propriedade plena do imóvel, o senhorio, que se despiu praticamente de todos os componentes patrimoniais, o domínio, tem igualmente interesse em manter o quid pecuniário da enfiteuse que constituiu. E não se pode, evidentemente, à guisa de ministrar equidade a um, fazer ao senhorio a iniqüidade de facultar ao foreiro o resgate compulsório.

Portanto, o dispositivo do resgate parece instituído muito mais em função de uma finalidade objetiva - a extinção dos aforamentos - do que fazer justiça ou prover equidade a qualquer das partes contratantes. 
E, se, por outro lado, a Suprema Corte entendia não ser possível o resgate de aforamentos constituídos anteriormente ao Código Civil, a legislação brasileira, ciosa do seu modernismo, acabava por agasalhar ad eternum, no seu seio, uma instituição já em franco desuso, uma reminiscência de épocas ul-
trapassadas.

Só afinal, em 1958, nos embargos opostos ao Recurso Extraordinário n: 21.590, em memorável julgamento em que foram partes, de um lado, a Municipalidade da cidade de São Paulo e, de outro, José Loureiro dos Santos Barreto e sua muIher, o Supremo Tribunal Federal mudou a sua orientação vindo admitir o resgate de aforamentos constituídos anteriormente ao

Acolhendo opiniões do maior prestígio (como, entre outras, as de Carlos Maximiliano e Orosimbo Nonato), no sentido de que, se a finalidade do resgate era a extinção do instituto e se este se revestia de um caráter perpétuo, não havia como sobrepor-lhe princípios de direito adquirido, sob pena de frustrar esses objetivos, entravar o progresso e impedir a integração do sistema jurídico nas conquistas sociais, o Supremo Tribunal mudou afinal a orientação.

$E$, não obstante a matéria ainda dividir juízes, e, vez por outra, ao sabor de composições eventuais de câmaras, um ou outro acórdão ainda resista ao resgate de aforamentos anter6.927, em que foram - como os embargos na Ap. Cível n? Metropolitana do Ar partes o Cabido da Santa Igreja Catedral neiro e Domingos Arcebispado de São Sebastião do Rio de Jabunal do Estado Gonçalves e sua mulher, julgados pelo Tri- Supremo Tribua Guanabara em 1963 -, tribunais locais e no sentido da conal Federal se orientam predominantemente Pretório Excelso, a ressão do resgate. No caso particular do do (RE n? 48.037, reiteração de julgamentos no mesmo senti27-12-62; RE n? 50, julg. em 24-5-62; RE n? 48.151, julg. em matéria merecesse 325 , julg. em 9-5-63 e outros) fez com que a pacífica, sob o n? 170 .

Mas, mesmo com

da Nação, que abrium a nova orientação da cúpula judiciária a matéria seja agora de caminho ao resgate, e conquanto terá que depositar a irrisórirgos de alçada, pois o foreiro só poucas têm sido as demanda quantia de vinte foros anuais, dade é que as crises econom visando a esse objetivo. A ver- 
inflação reduziram a nonadas as pensões. E estas, longe de constituir ônus financeiro, pela sua inexpressividade, ${ }^{10}$ passaram a ser um mero incômodo, nem sempre capaz de incentivar o foreiro a buscar a demanda, tanto mais quanto o laudêmio, pela sua estrutura semelhante à de um imposto; o alienante transfere-o para o adquirente, acrescentando o seu valor ao preço do negócio.

10 No Brasil, a maioria das enfiteuses regidas pelo Código Civil são eclesiásticas e remontam às sesmarias concedidas pela Coroa Portuguesa a jesuítas e a outras ordens religiosas. As ditas profanas são, em geral, de Direito Público. Ao que se sabe, o Estado da Guanabara contesta vivamente o pretendido aforamento que a família Silva Porto sustenta ter sobre terras situadas no bairro de Botafogo. A família imperial do Brasil tem enfiteuse de terras de Petrópolis etc.

Data das respectivas fundaçōes; as sesmarias outorgadas pelos monarcas portugueses à maioria das municipalidades brasileiras, ou, como se chamava àquela época, ao Senado da Câmara, para que elas, aforando as terras assim recebidas, auferissem renda para custelo de seus serviços e promovessem o crescimento das povoaçôes. Era o mesmo gene jurídico-social que possibilitou o aparecimento dos burgos medievais. Ali como aqui, o instituto tinha dúplice finalidade: prover rendas e estimular as construçöes em suas terras através das concessões enfitêuticas. Lá os burgos giravam em torno dos príncipes que permitiam as edificações nas cercanias de seus castelos. Essas células-máter dos atuais centros urbanos tinham suas cartas de foral outorgadas pelos príncipes. Outorgando enfiteuses e estabelecendo os forais, que eram um conjunto de regras por ele ditadas para reger a vida comunitária que se erigia sob seu assentimento e proteção, o nobre, ao mesmo tempo que Ihes dava proteção e leis corporativas, Ihes cobrava rendas para sustento de seu aparato nobiliárquico. Estavam lá todos os ingredientes do condado ou município moderno. Havia um mecanismo tributário, se bem que extremamente rude, o exercício de um poder de polícia, uma lei local, uma submissão e, portanto, uma jurisdição. Aqui os elementos eram substanclalmente os mesmos; apenas o personalismo do príncipe era substituído pela entidade impessoal do Senado da Câmara. O instituto, nas suas linhas mais puras; conseguiu sobreviver a séculos e, até hoje, se bem que com mudanças substanciais de concepção e estrutura, subsiste. Muitas municipalidades brasileiras detêm ainda o aforamento das terras onde primitivamente se fundaram, sendo as mais expressivas, pela importância que então assumiam, as sesmarias da cidade do Rio de Janeiro, da cidade de Săo Paulo, Bahia e Recife. Escusado dizer que, a despeito do zelo com que os respectivos funcionários administram esse patrimônio, o serviço é altamente deficitário. Os foros anuais e os laudêmios eventuais, que, àquela remota época, acorriam aos serviços dos Senados das Câmaras, hoje sequer pagam o respectivo serviço de arrecadação, figurando esse patrimônio no acervo das cidades, mais como uma relíquia do que um elemento de expressão econômica. Interessante sob todos os aspectos o trabalho realizado por Joăo da Costa Ferreira sobre o patrimônio imobiliário da cidade do Rio de Janeiro e publicado no Volume 5 ? da Revista da Procuradoria do Estado da Guanabara, onde o historiador, relata, com impressionante riqueza de detaIhes, as peripécias da medição e demarcação das sesmarias da cidade Outorgadas por seu fundador Estácio de Sá e depois confirmadas e ampliadas por Mem de Sá. Ao que parece, havia uma superposição de glebas 


\section{Parte Segunda}

\section{TERRENOS DE MARINHA}

CAPITULO I nar e origens.

§ 2. - Um pouco de Direito Comparado.

fins.

$\S 3$ ? - A legislação atual sobre marinhas e seus

$\mathrm{Na}$ forma da legislação em vigor (Dec.-lei n.o 9.760, de 16 de setembro de 1946), são terrenos de marinha, em profundidade de 33 metros medidos horizontalmente para a parte da terra, da posição do preamar médio de 1831 , os situados no continente, na costa marítima e nas margens dos rios e lagoas, até onde se faça sentir a influência das marés.

Esta a definição legal. Podemos, porém, simplificando a idéia, dizer que, para caracterizar-se e identificar-se os terrenos de marinha, toma-se a linha do preamar médio de 1831 e mede-se para dentro da terra 33 metros. Toda área compre-

entre as sesmarias outorgadas à cidade e outra outorgada à Companhia de bém (região dos engenho velho e engenho novo, onde os religiosos tamveio frustrar durama atividade agrícola). Esse fato, segundo o historiador, ao qual os jesuítas opunham demarcação e medição do termo de sesmarias, - que só veio ocorrer muito sucessivos embargos, eternizando a demanda, então investido no poder, muito mais tarde, quando o Marquês de Pombal, contra os jesuítas. Abandeu mão forte ao Senado da Câmara da cidade para nos atermos à épondonando o campo das reminiscências históricas, dados alienigenas sobréca atual, impõe-se ainda dizer que não se têm instrumento adequado a utilização, nos tempos atuais, da enfiteuse como lei francesa de 1919, à qual seção de terras. Não se sabe, v.g., se a célebre tinua em vigor; ou, à qual se refere Washington de Barros Monteiro, conexistem extensas glebas qualquer sorte, pelo menos nas Américas, onde presta serventia a pro por integrar ao sistema produtivo, o instituto ainda que parece, a fórmula jurís de ocupação e colonização. No Brasil, ao sendo, durante séculos, adota está superada. De fato, a enfiteuse vinha ideal à ocupação de terras inta na legislação brasileira como instrumento lei de terras do Brasil - Assim é que já o era na primeira sivamente até o mais recente ${ }^{\circ} 605$, de 1832 -, e assim vinha sendo sucesNo Estatuto da Terra, porém Dec.-lei n? 7.960, de 14 de setembro de 1946 . outubro de 1964, que instituiu como é chamada a Lei no 4.504 , de 9 de leiro da Reforma Agrária, esse reforma agrária e criou o Instituto Brasinado. No diploma legal, onde esquema jurídico foi inteiramente abandoas terras públicas (à exceção se atribui ao IBRA a administração de todas 
endida nessa faixa, ou que a ela acresceu, ou venha acrescer, natural ou artificialmente, é terreno de marinha. $E$ mede-se o preamar não só da orla marítima, como das margens de lagoas e rios, até onde se faça sentir a influência das marés.

Dessa forma, toda a costa marítima brasileira, bem como as margens de rios e lagoas, sob a influência de marés, na largura daquela faixa, ou a que a ela acresceu posteriormente, é de propriedade da União Federal, a título de marinhas.

Essa caracterização, extremamente antiga, não sofreu qualquer modificação, nem se adaptou ao decurso do tempo. Declarada a Independência, a legislação brasileira simplesmente incorporou ao seu sistema o que dispunha, a propósito, o velho Direito português aplicável à colônia de além-mar.

De fato, segundo o magistério de J.E. Abreu de Oliveira ("Aforamentos e Cessão de Terrenos de Marinha", Imprensa Universitária do Ceará, ed. 1967, pág. 42), em 18 de novembro de 1818, uma ordem emanada da Coroa Portuguesa determinava e vinha definir que "tudo o que toca a água a acresce a ela é da Coroa na forma das ordenações do Reino; e que da linha-d'água para dentro sempre são reservadas 15 braças pela borda do mar para o serviço público." E, segundo o antigo sistema de medidas - que se subdividia em braça, craveira, palmo, polegada etc.,- 15 braças correspondiam exatamente a 33 metros.

Pelo que se vê, pois, pouco ou quase nada se acrescentou à definição de 1818 do velho Direito português. Apenas estabeleceu-se a data do preamar médio como sendo a existente em 1831 , com o objetivo de uma referência no tempo, uma vez que havia de se identificar e demarcar os terrenos e os acrescidos evidentemente fazem recuar o alcance das marés.

Por outro lado - de parte sua irredutibilidade, que vem desafiando séculos - os terrenos de marinha, ao que apurou Renato Franco (Terrenos de Marinha e outros Estudos, ed. 1928, apud J.E. Abreu de Oliveira, ob. cit., pág. 34), é uma instituição sem paralelo, sendo própria e peculiar ao Brasil.

ente promover seu aproveitamento segundo as necessidades da Nação, falase em venda, segundo módulos rurais; a empresas, cooperativas e famílias, conforme os planos oficiais de implantação da Reforma. Não se toca em enfiteuse como método de ocupação. E, noutra parte, regulando as relações entre proprietários e colonos, a lei fala em arrendamento e em todas as formas conhecidas de parcerias rurais. Ali também não se cogita de aforamento, que, como se vê, parece superado como fórmula de integração do binômio homem/terra. 
Segundo assevera, nem as próprias ordenações portuguesas, de então, aplicáveis à Metrópole, cogitavam do instituto, que, assim, era peculiar à colônia. Por assim dizer, uma invenção do velho Direito português para ter aplicação tão-somente ao Brasil.

Os Direitos, quer dos países europeus, quer dos americanos, tratam as praias como bens dominicais, ora de uso especial, ora de uso comum do povo e, como tanto, sujeitas a uma regulação administrativa especial. Mas nenhuma trata dos terrenos de marinha como bens de natureza patrimonial, tal como
existe no Brasil.

De fato, o Código Civil argentino, v.g., caracteriza as praias como bens públicos, ligadas ao interesse da navegação. Da mesma forma, prescreve o Direito italiano (D'Allessio, Instituzioni di Diritto Amministrativo, vol. II, pág. 369), bem como o Direito Administrativo alemão, afetando as praias à pesca e navegação (OTTO MAYER, Direito Administrativo Alemão, vol. III, pág. 181). Nenhum trata a orla marítima como bem patrimonial.

Atualmente, os terrenos de marinha, bens patrimoniais da União Federal, são administrados por um órgão específico Fazenda, através ónio da União - vinculado ao Ministério da ou aforamento, in dois instrumentos principais. A enfiteuse losóficos já conhecidumento de origem e contornos jurídico-fium critério sem muito, e as ocupações, que representam mais administração públo fundo jurídico, criado e aplicado pela relações com os indiva à sua conveniência para regular suas

no tocante a seus bens imóveis.

E o objetivo desta administração, ao que se supõe, é precipuamente, obter renda. Não no sentido de lucro, pois que esse, na sua acepção rigorosa, é estranho aos fins públicos, mas, presumivelmente, no de obter rendas patrimoniais líquidas (receita patrimonial superior ao custeio dos respectivos serviços), a fim de aplicá-los na consecução do bem público.

Isto posto, à luz do que se escreveu e se transcreveu e, de qualquer modo, esteve a nosso alcance, vamos procurar intuir as razões pelas quais se instituíram, entre nós, os terrenos de marinha. E, depois, fazendo pequena retrospectiva do insordem patrimonial, corpo jurídico. 


\section{CAPITULO II}

$\S 10$ - Terrenos de marinha no velho Direito português. A intenção e objetivos da Coroa Portuguesa. O serviço público e o aforamento.

§ 2 - - Terrenos de marinha no Império e na República. As marinhas sob administração das Câmaras locais e sob administração da União Federal. Seus traços característicos.

Pelo que se depreende de textos das ordenações portuguesas, colhidas, aqui e ali, por J.E. Abreu de Oliveira, Manuel Madruga, Renato Franco, Themistocles Cavalcânti e outros, a Coroa Portuguesa - a quem, aliás, não faltou sentido prático - tinha nitidamente dois objetivos quanto à orla marítima brasileira. Reservar as praias propriamente ditas para o serviço público. Mais precisamente à navegação e à defesa da costa. Aforar certos terrenos, como mangues, fundos de baí, lagoas etc., que, por sua natureza, conquistáveis à água, pudessem se prestar a edificações e expansão das povoações. Era a aplicação na colônia do velho instituto da enfiteuse, mais uma vez chamado ao papel de incentivador da ocupação da imensa costa brasileira.

Um simples e despretensioso exame de atos da Coroa Portuguesa, de então, bem convence disso.

Já vimos que ordem régia de 1818 dizia peremptoriamente "que tudo que toca a água é da Coroa na forma das ordenações do Reino; e que será sempre reservada uma distância de 15 braças pela borda do mar para o serviço público".

Por outro lado, segundo refere José Tavares Bastos, já anteriormente, um alvará real expedido em 1732 ordenava ao Governador do Rio de Janeiro que não consentisse pessoa alguma apropriar-se das praias e mar por serem de uso comum (Abreu de Oliveira, ob. cit. pág. 47).

Ainda uma ordem régia de 1710 rezava que a "sesmaria nunca deveria compreender a marinha, que sempre deve estar desimpedida para qualquer incidente do meu serviço e defesa de terra" (ob. cit., pág. 50).

Já quanto a mangues, lagoas e bacias de mar, suscetíveis de serem aterrados, outro era o espírito. Rezava uma ordem régia de 1678: "Esses mangues eram da minha regalia por nascerem em salgado onde só chega o mar, e com a enchente serão necessários para a conservação desse povo, engenhos 

e navios" (Themístocles Cavalcânti, Tratado de Direito Admi-
nistrativo, vol. V, pág. 407).

Aqui a propriedade era da Coroa, não em razões de serviço público, mas porque a enchente (seu aterro) seria necessária ao povoamento, engenhos etc. das populações ribeirinhas.

Por outro lado, uma decisão de 11 de outubro de 1847 também declarava que, "quando os particulares quisessem aterrar o mar para segurança de seus prédios a ele fronteiriços ou para novas edificações, se Ihes conceda aforamento, a título de marinha, quando daí não venha prejuizo ao porto, à 1928, vol. I, pág. 95).

Vê-se, pois, sem sombra de dúvida, que, no entendimento da antiga Metrópole, as praias seriam bens afetados ao serviço público. Certas partes, porém, do litoral suscetíveis de aterro eram de propriedade da Coroa, já na qualidade de bens patrimoniais. E, mediante aforamento, eram outorgados, para esse fim, a quantos se interessassem pela empreitada, aumentando as áreas úteis das povoações litorâneas então surgentes.

Imbuída do espírito colonizador e, ao mesmo tempo, interessada em auferir rendas de sua nova colônia, a Coroa Portuguesa reservou 15 braças ( 33 metros) para o serviço público ra, ob. cit) aliás, fazia em relação à sua costa (Abreu de Oliveimediante a enfiteuse desprezou a oportunidade de promover, goas, alagados etc. o aterramento dos fundos de baías, lamar, pudessem ser apre, por sua natureza, recuperáveis ao vilas ribeirinhas.

Ao mesmo tempo em que, no afã de colonizar, dava em sesmarias terras interiores, reservava, a si, o privilégio de timada, pelas áreas, que, então, pela extensão da costa espareciam de quantidade de mangues, lagoas, alagados, Ihe

muito expressivo.

os terrenosada a Independência, a lei brasileira passou a reger servados os mesminha, mantida a mesma conceituação e observiço público, a quanto. Aforar aqueles não necessários ao contribuindo para quantos quiserem recuperá-los e edificá-los, Assim

rial transferiu que, tão logo passou a legislar, o Governo Impeas marinhas e ara as Câmaras Municipais o direito de aforar marinhas e cobrar os respectivos foros e laudêmios. 
De fato, já na lei de 15 de novembro de 1831 (art. 15, § 14) se dispunha: "Serão postos à disposição das Câmaras Municipais os terrenos de marinha que estas reclamarem do Ministério da Fazenda ou dos Presidentes das Províncias para logradouros públicos. E o mesmo Ministro da Corte e, nas Províncias das Cortes, os Presidentes, em Conselho, poderão aforar a particulares aqueles tais terrenos que julgarem convenientes e segundo o maior interesse da Fazenda, estipulando também, segundo for justo, o foro daqueles mesmos terrenos onde já se tenha edificado sem concessão, ou que, já tendo sido concedidos condicionalmente, são obrigados a eles desde a época da concessão."

Mais tarde, a Lei imperial no 38 , de 3 de outubro de 1834 (art. $37, \S 2 \%$ ), consolidou e reiterou a disposição anterior, transferindo à Câmara Municipal do Rio de Janeiro o direito de arrecadar foros dos terrenos de marinha compreendidos no seu Município. O mesmo fazendo a Lei $n$ ? 3.348 , de 20 de outubro de 1887 (art. 5\%), que autorizou, genericamente, a transferência para as municipalidades de todo o País dos direitos de aforar e cobrar foros e laudêmios (J. E. Abreu de Oliveira, ob. cit., pág. 60 ).

E era natural que assim fosse, pois, se o fim desses aforamentos era promover a expansão e povoamento das cidades litorâneas, o interesse era precipuamente local. $E$ ao ente local devia incumbir o desiderato.

Dessa forma, durante o Império e sob diversas leis autorizativas, as Câmaras locais não só aforaram os terrenos de marinha e receberam as respectivas rendas, como tinham expressas recomendações de fazê-lo, em benefício dos núcleos populacionais.

No preâmbulo do Decreto imperial no 4.105 , de 22 de fevereiro de 1868, que se reporta a diversas leis anteriores, está claramente indicada a intenção dominante na concessão dos terrenos:

"Reconhecendo quanto é importante semelhante concessão (a enfiteuse), a qual, além de conferir direitos de propriedade aos concessionários, torna dito terreno produtivo e favorece, com o aumento das povoações,

- das rendas públicas"

(apud J. E. Abreu de Oliveira, ob. cit., pág. 50).

$E$, efetivamente, desta época data, entre outras, a recuperação feita pela cidade do Rio de Janeiro do saco de S. Diogo, um extenso alagado que, partindo da praia de São Diogo, en- 
trava terra a dentro, abrangendo a área hoje conhecida como canal do Mangue e adjacências. Erijiu-se ali uma cidade nova com o recurso amplo ao aforamento. As atuais Ruas Pereira União Federal, a título ânti e outras são foreiras ainda hoje à verno local.

Proclamada a República, a Lei nọ 25, de 30 de dezembro de 1891, fez reverter à União Federal o privilégio de que gozade Rio de Janeiro só reverteram muito mais tarde, pelo Dec.-
le 710 , de 17 de setembro de 1938 .

Começou então propriamente a fase em que a União $\mathrm{Fe}$ deral veio administrar os terrenos de marinha, citando-se, a pro1940, Dec.-lei nuintes leis: Dec.-lei no 2.490, de 16 de agosto de 4.120, de 21 . 3.438, de 17 de julho de 1941, Dec.-lei n? lei no 9.760, de 16 deiro de 1942, e, finalmente, o atual Dec.-

Uma fase 16 de setembro de 1946.

pitais de filosofia quantratretanto, apresentam diferenças cabens. Ao passo em quanto ao modo e fins de utilização desses marinhas não fugiu, que, durante o Império, a legislação sobre Coroa Portuguesa, vindo princípio, aos objetivos delineados pela de aforar aqueles que, outorgar às entidades locais o direito sem resultar em prove, dispensáveis ao serviço público, pudesperíodo posterior, a União do crescimento das povoações, no rio o processo de juimou por relegar a plano secundámente de um critérioramento, passando a se utilizar larga-

A reversão fundo muito jurídico - as ocupações. se operou senãos terrenos de marinha à União Federal não micas.

Quando da Proclamação da República e da instauração do peculiaridades do regime, passaram a constituir unidades aua porção de terras devolutas situadás nos seus territórios, remente, deu origem à polêxa de fronteiras. Esse fato, possivelmarinhas, participando da nat pois alguns entendiam que as veriam também passar da natureza das terras devolutas, dequanto assim abonava domínio dos entes locais, tanto mais Vozes do maior a tradição imperial. cio Pessoa, Bandeir prestígio, como as de Rui Barbosa, Epitáponto de vista, afinal de Melo etc., se levantaram sustentando o que as marinhas, embora su- 
jeitas ao mesmo regime de utilização (aforamentos, concessões etc.), não eram terras devolutas, mas, pela sua origem histórica, sempre foram de propriedade do poder central, sendo os entes locais, até então, meros usufrutuários das respectivas rendas (Themístocles Cavalcânti, Tratado, vol. V, págs. 407 e seguintes).

Talvez esse fato, essa árdua luta doutrinária - porque tivesse gerado no poder central uma impressão de usurpação talvez o conflito mundial que então se desenvolvia e lançava as Américas numa tensa expectativa de defesa, ou talvez o próprio regime forte que vigia à época - o fato é que a União Federal, tão logo passou a administrar os terrenos de marinha, traiu os fins sumamente práticos a que foram criados.

Relegou a plano secundário a enfiteuse como instituto capaz de propiciar a recuperação de alagadiços das cidades ribeirinhas e passou a manipular apenas as posses nesses terrenos - as chamadas ocupações -, atribuindo-Ihes um caráter precário e, como tanto, truncando seu natural desenvolvimento.

Com efeito, com a promulgação do Dec.-lei $n$ ? 2.490, de 16 de agosto de 1940, o aforamento de marinhas deixou de ser um ato rotineiro de administração e destinação desses bens, para assumir um caráter excepcional, a critério do Poder Executivo.

Conquanto previsto em lei, as autoridades fazendárias federais passaram a entendê-lo não como uma medida usual e programática na administração daqueles bens, mas como uma faculdade do Presidente da República a ser ministrada com extrema moderação e parcimônia. Alguns, até esquecidos dos contornos doutrinários do instituto e seus fins - eminentemente colonizadores, que, exigindo um árduo e prolongado trabalho do solo, deveria ser, por natureza, perpétuo -, propunham que se os concedesse para fins unicamente relevantes e de utilidade pública, rescindiveis ao cabo de três anos se não implementadas as condições.

E, mesmo quando decidido o aforamento, só teriam a ele direito (preferência) os ocupantes que, à data da lei, estivessem pagando as respectivas taxas de ocupação; os já à época titulares do domínio útil, quanto aos acrescidos; os não inscritos, mas com ocupação anterior a 1940 e com benfeitorias consideráveis no terreno; os portadores de escrituras públicas na suposição de ser o imóvel alodial etc. (art. 10); os que viessem ocupar terrenos de marinha posteriormente a esta data não teriam preferência a aforamento. No dizer peremptório da lei, a União não thes reconhecia qualquer direito. 
O Dec.-lei n: 3.348 , de 20 de outubro de 1941, bem como outros provimentos posteriores, repetiram os mesmos princípios. E, finalmente, o atual Dec.-lei no 9.760, de setembro de 1946, reitera a mesma sistemática estabelecida em 1940 (arts. 104 e
seguintes).

Desse modo, se o aforamento de marinhas é agora medida excepcional e traindo as próprias raízes do instituto, reservado para casos relevantes de utilidade pública; e, se, de qualquer forma, decidido este, só terão direito a eles os ocupantes anram à administração federal), a União simplesmente truncou um natural processo de recuperação de mangues e alagados da
costa maritima brasileira.

Sim, porque mesmo os ocupantes anteriores a 1940 não investiriam recursos expressivos na sua recuperação com um instrumento extremamente inseguro e que, à ausência de um caagentes administrativos.

E os ocupantes

dizendo drasticateriores a 1940, aos quais a lei vai logo com maioria de razão não reconhecer qualquer direito, esses, não fosse transitória

e fato, $q$ r.

teriza? Em que instrumento jurídico é este? Como se caracse. Que efeitos consiste? Trata-se, evidentemente, de uma postorias, que tratam The atribui? A lei não os enuncia. As benfeitério? Preço histórico recebem? São indenizáveis sob que cridem ao solo? Em ou de reprodução? São retiráveis ou aceprincípios constitu caso de utilidade pública, respeitam-se os o procedimento dionais que garantem a propriedade? Usa-se de desocupação, tenapropriatório normal ou medidas sumárias simplesmente ocupado?

A propósito, a lei riores a 1940 têm direito limita a dizer que as ocupações anteteriores a União não reito de preferência ao aforamento; às pose outras, à semelho reconhece qualquer direito. E sobre umas de ocupação e, evenţa da enfiteuse, cobram-se módicas taxas se - em matéria de mente, laudêmios. O que - convenhae conceituação, é dizer nada. mesmo - da ausência do casuísmo da lei - e talvez por isso circulares estab variedade extraordinária de portarias, avisos, 
interpretadas por meros agentes administrativos das Delegacias do Serviço de Patrimônio, às mais das vezes bem intencionados, mas sem discernimento profissional para o trato do problema. (Das portarias, sem dúvida, uma das mais extraordinárias é a de n: 305 , de agosto de 1965, que, invocando abusos verificados, impede que os ocupantes façam benfeitorias de grande porte nos terrenos ocupados. Desvirtuando completamente os fins a que visa, o provimento quer impedir simplesmente que 0 ocupante consolide sua ocupação, vendo, ao prisma do esbulho e da usurpação, um ato que não é senão conseqüência lógica da ocupação tolerada.)

Só para exemplificar - e em outras partes do Brasil haverá, por certo, exemplos muito mais contundentes -, no fundo da baía de Guanabara, em regiões do Estado do Rio de Janeiro, desembocam 53 rios, que, aos poucos, vão aterrando o local. Grandes e extensos mangues, impróprios a qualquer atividade, até a pesca miúda, ali se formaram.

Pois bem! Essa região de recuperação necessária está praticamente abandonada, quer porque sua ocupação só se deu, em termos definitivos, em época recente, depois do saneamento da Baixada Fluminense, quer porque o processo de formação de mangues é, por sua natureza, lenta. E, atualmente, em face da orientação que se empresta aos terrenos de marinha, ninguém vai-se lembrar de investir no seu aproveitamento, através de um título dúbio e inseguro - as ocupações precárias.

Mas por que essa orientação? Por que se abandonou 0 modus do Império, para se adotar essa política peculiar, que, longe de facilitar a recuperação do litoral, tende a agravar mais o problema com o decorrer do tempo?

De parte as possíveis razões ligadas à tumultuada reversão desses bens ao domínio da União, ao fato da guerra então em desenvolvimento, ou quaisquer outras, alega-se, em princípio, que as ocupações possibilitam a arrecadação de maiores rendas, pois, ao passo que o aforamento, sendo perpétuo, não permite modificações na sua estrutura econômica, as taxas de ocupação são periodicamente revistas, além de serem em 0,4 (quatro décimos) mais altas do que os foros. (A taxa é cobrada à razão de $1 \%$, e o foro, à razão de $0,6 \%$ sobre o valor do imóVel.) Alegam-se razões de estratégia ligada à defesa da costa e facilidade de desocupação dos terrenos, vindo-se, eventualmente, deles precisar para o serviço público. 
CAPITULO III

$\S 10$ - A inutilidade dos terrenos de marinha como instituto. Formas para sua extinção.

Verifiquemos agora se qualquer das razões invocadas ou outras que possam existir justificam a manutenção, quer da orientação que atualmente lhe empresta a União Federal, quer do próprio instituto entre nós.

Vejamos, em primeiro lugar, o problema da estratégia. E, aqui, antes de ferirmos o tema, faz-se mister estabelecer a distinção entre terreno de marinha, bem do domínio federal, de natureza patrimonial e as áreas de mar batido, que, embora compreendidos na conceituação genérica de marinhas, não gra,em ser levados à conta de bens patrimoniais, pois, em remar.

Quanto aos últimos, muito embora as regras de guerra tenham e, ainda hoje, venham sofrendo sensíveis modificações, derar. E esse não é problema para o presente trabalho resolver, melhor dizendo respeito às Forças Armadas. Mas é evidente que, quanto aos primeiros - os terrenos
aterrados -, sob regime de aforamento ou ocupação, nenhum
é o interesse estratégienter é o interesse estratégico. São áreas que, pouco a pouco, conquistadas ao mar, se encontram, na verdade, em terra firme do litoral.

emprego do re fala em estratégia como motivo, quer para 0 ção do instituto essa distinção básica nós, em realidade, se está esquecendo com a extinção dos e essencial. Está-se esquecendo de que, prédios e terrenos situados de marinha, se pretende desagravar tros do litoral e não entrem terra firme e a centenas de mede mar batido.

E nem razões de facilidade de desocupação da orla marítima, para sua eventual destinação a um serviço público, podem instituto. e, em casos excepcionais, existe o instituto da desapropriação civil etc., as requisições, como grave comoção interna, guerra desses bens em isições, nenhum sentido faz a conservação ou eventualidade estado de quase esterilidade, na suposição de obras públicas, sequer ainda planejadas. 
O senso comum, na sua manifestação mais rudimentar, recomenda seu aproveitamento econômico, utilizando-se, mais tarde, as desapropriações ou requisições, se tanto necessário.

E, na verdade, muito mais prática, pelo efeito multiplicador que acarreta (arrecadação de impostos, crescimento da demanda de empregos, expansão de áreas úteis etc.), a integração dessas áreas no complexo econômico local do que mantê-las em estado de esterilidade, na expectativa de vir desembaraçálas ao serviço, sem ônus indenizatório.

Por outro lado, não nos parece, igualmente, que razões de ordem patrimonial possam constituir motivo para a manutenção quer do regime de ocupações, quer do próprio instituto.

Com efeito, já em 1942, uma comissão então nomeada pelo Governo para estudar o problema da enfiteuse sob suas diversas modalidades, da qual faziam parte nomes como os de Orosimbo Nonato, Hannemann Guimarães, recomendava, em suas conclusões, a extinção dos aforamentos de terrenos de marinha, por se tratar de atividade deficitária (Alfredo de Almeida Paiva, Rev. de Dir. Adm., vol. VIII, págs. 514 e seguintes).

$\mathrm{E}$, se, já àquela época, segundo estudos procedidos, os terrenos de marinha proporcionavam rendas inferiores aos gastos com a manutenção dos respectivos serviços, hoje, muito embora poucos aforamentos se tenham constituído de então a essa data, esse deficit só deve ter aumentado.

$\mathrm{Na}$ verdade, a conjuntura rudemente inflacionária que experimentou o Brasil ao longo de duas décadas deve ter onerado o custo dos serviços de manutenção em proporções bem maiores do que os reajustamentos de taxas de ocupação que se tenha podido fazer no mesmo período.

Não temos em mãos dados estatísticos que apropriem essas receitas e despesas. Mas, sem dúvida, uma comparação dessas contas irá demonstrar um deficit bastante expressivo.

Acresce mais, a propósito, que o Serviço de Patrimônio da União, até então, administrava não só os terrenos de marinha, como as terras devolutas pertencentes à União, além de outros próprios eventualmente não utilizados no serviço pú-
blico.

Ocorre, agora, porém, que, pela Lei n? 4.504, de 30 de e vembro de 1964, que dispõe sobre o Estatuto da Terra Q dá outras providências, as terras públicas da União terão Prioridade na implantação da Reforma Agrária (art. 10, § 19) 

e passarão, evidentemente, à jurisdição do Instituto Brasileiro
de Reforma Agrária.

Dessa forma, se, antes, as despesas de custeio dos respectivos se distribuiam por uma série de atividades, agora serão primordialmente imputadas às marinhas, aumentando o de-

dos números abandonando-se o problema ligado à grandeza de rendas auferide ainda acentuar o seguinte. O maior volume título de laudêmio. tual, pois, só ocupação dos terreno alguém transfere o domínio útil ou a o recurso é eventual, não que ele é devido. E, se assim é, se cer com base nel, não há programa que se possa estabelecontar nos exercícios.

$\mathrm{Na}$ administração da coisa pública, pelo complexo de leis que regem seu funcionamento, pela natural delonga no tomarque propriamente importa saber quanto se pode dispor, do de um exercício dispor de tanto. Os planos são elaborados recursos disponíveis, outro, e, sem uma estimativa real dos

13 de julhois nos 3.421, de 10 de julho de 1958, e 4.089, de marinha passa 1962, o produto da arrecadação sobre bens de rio Nacional, adm constituir, parte, receita do Fundo PortuáPortos, Rios e Caninistrado pelo Departamento Nacional de de Saneamento. Seris, e, parte, do Fundo Nacional de Obras quias puderam fazer a caso de verificar-se o que essas autar-

no Brasil ver, pois, nenhuma razão existe para manter-se em realidade, razõ instituto dos terenos de marinha. Não há, menos, patrimonial de ordem política ou estratégica e, muito

Muito ao contrário, não só o serviço é deficitário, como, pelo que se viu, a orientação que Ihe tem emprestado a União Federal só tem frustrado a recuperação do litoral em termos adequados, pela instabilidade evidente do instrumento jurídico ramento.

Dentro do espírito da Reforma Administrativâ, urge extingui-los, rompendo com uma tradição secular e desnecessária,
vindo ao encontro 
E, para fazê-lo, evidentemente, não se lançaria mão da velha solução tantas vezes aventada: a remição progressiva dos aforamentos.

É que, ao que se sabe, de 1940 a esta data, poucos aforamentos se constituíram. E, a se optar por essa solução, a União teria, em primeiro lugar, que aforar as atuais ocupações e remi-las ao cabo de 20 anos, acontecendo, então, que não só os terrenos de marinha, como instituto, só acabariam por volta do ano 2000, como a administração, por amor a esse expediente, iria, extravagantemente, constituir um negócio, vetusto, superado e deficitário e arcar com seu formidável prejuizo durante ainda duas décadas.

Acresce que o sofisticado ponto de amarração das marinhas - preamar de 1831 - tem, na verdade, à ausência de cartas e mapas fiéis à época, retardado sua medição e demarcação, e, em certos trechos do litoral, não se sabe, a rigor, o que aforar.

No intuito de extingui-lo, poder-se-ia usar de três princípios fundamentais, a seguir enunciados, na sua generalidade, tom a preocupação de descer a pormenores e desdobramendo analíticos, uma vez que tal refoge à natureza e à extensão do presente trabalho.

Como primeira providência, abolir-se-ia o instituto dos terrenos de marinha, que tem-se prestado a grandes perplexidades ao longo desses anos, pois, na sua conceituação, abrange tanto bens patrimoniais, como aqueles que, por sua natureza, devem ser de uso comum do povo, sujeitos a regulamentação administrativa - as praias.

A lei poderia, ouvidos os órgãos técnicos e desprezados os dados do preamar médio de 1831, fixar simplesmente uma riam do litoral, na qual, através de regulamentação, se traçanão normas de sua utilização: servidões administativas de segundo construir; proibição de retirar areia, ou mesmo de aterrar, existir.

Em segundo lugar, poder-se-ia dispor que os proprietários ribeirinhos poderiam aterrar mangues alagados, aumentando suas áreas, desde que obtida autorização do órgão técnico a Capitania dos Portos - , a qual, nada havendo a obstar, sob a ponto de vista técnico, daria a autorização. Uma vez feito o dierro, seu proprietário faria uma planta com as devidas mebiliárís e confrontações, levando à inscrição no registro imo- 
Os atuais foreiros e ocupantes de terrenos já formados por aterramento poderiam convertê-los ao seu domínio particular. Os foreiros pela remição imediata do aforamento, tornando-se proprietários alodiais. Os ocupantes, justificando suas posses para levá-las ao registro imobilário, transformando-as em
domínio.

Dos foreiros e ocupantes cobrar-se-ia apenas a importância de 20 foros, ou taxas de ocupação, para esse fim.

Sendo terrenos criados pelo esforço e pelo capital de seus titulares, nenhum sentido teria cobrar-se laudêmio ( $5 \%$ sobre o valor do imóvel). Se o terreno foi criação material de seus titulares, para o qual a União não entrou com qualquer participação de riqueza, a cobrança do laudêmio implicaria numa taxação odiosa e indireta do trabalho humano, incompativel hoje com a filosofia fiscal. Implica em abonar princípios regalistas, hoje rejeitados pelo Direito moderno. Os foros e taxas seriam cobrados para custeio dos serviços administrativos de
desagravo dos imóveis.

Paralelamente, extinguir-se-ia o Serviço de Patrimônio da União, passando seus funcionários, se for o caso, a serem lotados em outras repartições fazendárias ligadas à arrecadação e à fiscalização de tributos, transferindo-se os serviços ligados ao mister à Capitania dos Portos, sendo, aliás, que a extinção do Serviço de Patrimônio da União já está programada no art. 125 do Dec.-lei no 200, que trata da Reforma Administrativa.

Com essas medidas assaz simples, poder-se-ia terminar com o velho instituto, que, como se viu, em nada mais aproveita
os interesses da Nação. O Dec.-lei no 200 , de 25 de fevereiro de 1967 , que vem
implantar a Reforma Administrativa, no intuito de aperfeiçoar 0
funcionamento do funcionamento do aparelho burac extinção de atos, aparelho burocrático federal, preconiza a modo, sejam apo, serviços, competências etc. que, de qualquer coisa pública.

A extinção do instituto dos terrenos de marinha, como se demonstrou, vem de encontro a esse fim colimado. Mostrou-se, através de rápida enunciação de suas linhas conceituais, aliada a uma breve e superficial perspectiva histórica, que o instrumenantes relevante qual se apóia - a eifiteuse ou aforamento - 
oportunidade nos dias atuais. Armada em torno de uma estrutura econômica extremamente peculiar - a perpetuidade do pacto e os foros, sobre serem imutáveis, irrisórios em relação ao valor do bem - a enfiteuse, de fato, conflita seriamente com a expressão e o significado patrimonial que têm atualmente os bens imóveis.

Por outro lado, o critério jurídico de que vem-se servindo, em maior escala, a União Federal - as ocupações precárias buscando seus componentes econômicos na imagem da enfiteuSe (taxa de ocupação anual e irrisória - 0,6\% - e, eventualmente, laudêmios) - não apresenta, à evidência, condições de produzir rendas patrimoniais líquidas, constituindo o serviço uma atividade deficitária, até porque não há, ao que é fácil intuir, entidade, por mais que comprima suas despesas administrativas, que possa auferir rendas sobre bens imóveis cobrando uma taxa de utilização em torno de $0,05 \%$ (meio centésimo) ao mês sobre o seu valor.

De parte, porém, essa circunstância, conforme também se demonstrou, a aplicação, em larga escala, das ocupações precárias, reservando-se os aforamentos para casos relevantes de utilidade pública, tem desvirtuado os fins precípuos a que se destinam as terras públicas - a colonização.

A ausência de regras precisas a regê-las, os próprios atos executivos complementares ora dizendo uma norma, ora outra, pelo clima de insegurança jurídica que geram, conspiram contra a adequada utilização das áreas tidas como de marinha, retardando sua integração no complexo econômico local.

$\mathrm{Na}$ intenção de extinguir os terrenos de marinha, não se cogitou da solução já muitas vezes aventada - o resgate progressivo dos aforamentos. Tendo-se em vista que, de 1940 a Usta data, segundo orientação do Serviço de Patrimônio da resero, poucos aforamentos se constituiram, pois a medida ficou lei rvada a fins de utilidade pública, e tendo-se em vista que a an atual só permite o resgate das enfiteuses ao cabo de 20 tura, depois de constituidos, cogitar daquela solução, nessa alas a seria não deixar à União outra alternativa senão aforar arcatuais ocupações e só vir a resgatá-las por volta de 1990, gravoso, nesse extenso ínterim, com o serviço extremamente pravoso de fiscalizar os contratos e recolher as pensões res-
pectivas.

que, Cogitou-se, por isso, de uma fórmula mais simples em reservando-se as praias ao serviço público, à navegação, 
à pesca, às instalações portuárias etc. - como, de resto, fazem outros países - , se permitisse os atuais ocupantes e foreiros transformarem os terrenos possuídos e aforados em propriedade plena e alodial, mediante o pagamento, no ato de transferência, dos respectiva compatível com o custeio do serviço de desagravo passaria a ser bens. A recuperação de mangues e alagados repartição técnica em vista possíveis - a Capitania dos Portos -, tendo-se Patrimônio da União interesses da navegação. E o Serviço de 125 do Dec-lei nọ serviços ligados à rec, de 1967, transferindo seus servidores e a ligados à receita tributária da União, se for o caso. 